\title{
OD DRAMATIZACIJE DO PREDSTAVE U NASTAVI ENGLESKOGA JEZIKA
}

\author{
Anamarija Bekavac* \\ Škola stranih jezika - Poliklinika za rehabilitaciju slušanja i govora SUVAG \\ i Poslovno veleučilište Zagreb \\ Tomislava Balić \\ Škola stranih jezika - Poliklinika za rehabilitaciju slušanja i govora SUVAG
}

\begin{abstract}
Cilj je ovoga rada prikazati proces stvaranja predstave na engleskom jeziku u okviru nastave za učenike osnovnoškolskog i/ili srednjoškolskog uzrasta. Osnovno je polazište ovoga procesa uporaba dramskih tehnika u nastavi engleskoga jezika. $U$ radu se navode najpoznatije dramske tehnike i prednosti njihove uporabe te opisuje proces pripreme predstave s brojnim primjerima. Proces započinje izborom teksta $\mathrm{i}$ adaptacijom scenarija, slijede prve čitalačke probe $\mathrm{i}$ dodjela uloga, rad na scenskom pokretu, izboru glazbe, scenografiji i kostimima. Potom slijedi opis potrebnog budžeta predstave, izrade promotivnog materijala te međunarodne suradnje. Predstava na engleskom jeziku veliki je projekt kojem prethodi osnivanje dramske radionice. Konačni rezultat uključuje edukativne, umjetničke i kulturološke sadržaje, stimulira motivaciju te generira novi pristup učenju engleskoga jezika.
\end{abstract}

Ključne riječi: adaptacija scenarija, dramske tehnike, nastava engleskog, predstava na engleskom.

\section{UVOD}

Cilj je ovoga rada prikazati proces stvaranja predstave na engleskom jeziku u okviru nastave za učenike osnovnoškolskog i/ili srednjoškolskog uzrasta. Osnovno je polazište ovoga procesa uporaba dramskih tehnika $u$ nastavi engleskoga kao stranog jezika.

Dramske tehnike $u$ učenju stranih jezika odavno su prepoznate. Sudjelovanje u dramatizacijama unutar vještina govorenja u nastavi engleskoga jezika navodi se i u Nacionalnom planu i programu za osnovnu školu (Vican i Milanović Litre, 2006) počevši od 1. razreda. Nadalje, dramske tehnike implementirane su u većinu udžbenika, posebno onih namijenjenih ranom učenju stranih jezika. Čak i kada u uputama za nastavnike nastavni materijali nisu metodički razrađeni koristeći se kao polazištem dramskim tehnikama, lako ih je primijeniti.

\footnotetext{
* anamarijabekavac@net.hr

** tomislava.balic@gmail.com
} 


\section{PREGLED LITERATURE}

Prednosti uporabe dramskih tehnika $\mathrm{u}$ nastavi stranih jezika teorijski su razrađene u brojnoj literaturi o ovom području (Belliveau i Kim, 2013; Dougill, 1987; Maley i Duff, 2013; Ntelioglou, 2011). Već pri prvim uporabama dramskih tehnika u učionici lako se premošćuje skok između teorije i prakse (Dundar, 2013).

Dramske tehnike prirodno povezuju kognitivno i afektivno učenje. Racionalno i analitičko često uzmiče pred emocionalnim što vodi do opuštenije uporabe jezika, rušenja barijere straha od mogućih grešaka $u$ jezičnoj produkciji i u konačnici do uživanja u uporabi stranog jezika (RyanScheutz i Colangelo, 2004).

Dramske tehnike ukazuju na važnost neverbalnih aspekata komunikacije afirmirajući poznatu povezanost zvuka i pokreta u jeziku (Gavrilović Smolić, 2019). Učenik koji samo sjedi u klupi, ma kako težio verbalnoj ekspresiji, ne može biti jednako uvjerljiv i uspješan u govornoj produkciji kao onaj koji se koristi i jezikom tijela. Prirodnost takve sinteze stoga rezultira većom lakoćom govorne produkcije.

Korištenje dramskih tehnika $u$ nastavi uvijek $u$ središte pozornosti stavlja značenje, a ne oblik. Jezik je uvijek u kontekstu što pozitivno utječe na atmosferu u razredu i razrednu interakciju. Naglasak je na vještinama slušanja i govorenja, ali povremeno se uvodi i vještina čitanja.

Nadalje, dramske tehnike $u$ nastavi snažno potiču samopouzdanje učenika (Boudreault, 2010). Iznenađujuće mnogo "tihih" učenika koji su povučeni, stidljivi ili bojažljivi u jezičnom izričaju potpuno mijenjaju pristup kada su uključeni u različite dramatizacije, te otkrivaju novu stranu svoje osobnosti. Čini se da igranje uloga ruši barijere suzdržanosti i potiče zajedništvo u projektu, a time i ležerniju govornu produkciju.

Uporaba dramskih tehnika potiče kreativnost učenika, stimulira njihovu maštu, znatiželju i želju za istraživanjem. To ima izravan utjecaj na razrednu atmosferu koja je vedra i pozitivna. Pritom učenici samo inicijalno slijede upute nastavnika te vrlo brzo oni sami postaju nositelji interpretacije kroz koju mogu dodavati svoje rečenice ili doskočice što će rezultirati nastavom u kojoj je učenik u središtu zbivanja.

Sve navedene prednosti uporabe dramskih tehnika u nastavi ukazuju na njihovu važnu ulogu u učenju stranih jezika. Ako su često korištene i ako u njima podjednako uživaju i učenici i nastavnici, ta razredna "kemija“" pokretač je motiva koji vodi dalje - u projekt postavljanja prave predstave.

Pretpostavke koje se pritom trebaju imati na umu su sljedeće: priprema predstave zahtijeva mnogo vremena te se često ne može raditi samo unutar zadane satnice stranoga jezika, niti ju je moguće pripremati samo jedan manji dio nastavnog sata. Stoga takav projekt često iziskuje angažman u slobodno vrijeme ili moguće osnivanje dramske radionice na stranom jeziku. 
Uz to, vrlo je teško pripremati predstavu s velikim razredima jer je teško naći aktivnu ulogu za svakog učenika. Grupne uloge (npr. Pripovjedač ili Pripjev) nisu popularne jer nemaju osobnost koju imaju drugi likovi u dramskoj predstavi.

\section{DRAMSKE TEHNIKE U NASTAVI}

Brojne se dramske tehnike mogu koristiti u nastavi (Lesar Dolenc, 2019; Nikpalj, 2015; Phillips, 1999), a mi navodimo one koje su prema našem iskustvu najuspješnije i koje uvijek imaju dobar odjek među učenicima.

Najjednostavnija i najuobičajenija je igra pantomime (engl. miming game) koja se koristi za sve dobne skupine. Tom se tehnikom možemo početi koristiti u nastavi za predškolsku dob, ali je jednako uspješna kod svih uzrasta. Tu je riječ o ekspresivnom načinu izražavanja pokretom i mimikom kojima pokazivač 'glumi' određeni pojam ili radnju, a onaj koji pogađa mora taj pojam verbalno izraziti.

Zatim slijede dramske tehnike koje uključuju razne igre asocijacija $u$ kojima dolaze do izražaja verbalne sposobnosti sudionika igre na osnovu slike kao poticaja (engl. pictionary) pri čemu jedan učenik crta zadani pojam, a drugi na osnovu nacrtanog pogađa o čemu je riječ. Uspješna je dramska tehnika i ona u kojoj slika služi kao poticaj za pričanje priče i stvaranje igrokaza. Učenici domišljato grade svoje priče na osnovi onoga što vide, a zatim to pretvaraju u kratke dijaloge.

U okviru igre asocijacija navodimo i igru „vruća stolica" (engl. hot seat) u kojoj jedan učenik sjedi na stolici okrenut leđima prema ploči, pokušavajući pogoditi zadani pojam koji ostali učenici u razredu vide. Igra se sastoji od toga da onaj koji pogađa postavlja pitanja na koja dobiva kratke odgovore.

Još jedna zanimljiva dramska tehnika je igra zamjena uloga (engl. role swapping) u kojoj učenici preuzimaju uloge odraslih ili učitelja, ili uloge suprotnog spola. Osim jezika ovdje se vježbaju pokret, mimika, ali i ritam i intonacija uvjetovane njima. Ponekad jedan učenik na papiru dobije natuknice o čemu je riječ, odnosno smjernice i prema njima započinje dijalog, dok drugi učenik mora na licu mjesta improvizirati.

Sljedeća popularna dramska tehnika je i ona koju smo nazvali walk like an Egyptian. Igra se sastoji u tome da svi moraju hodati poput osobe koju zadaje nastavnik - npr. kao dama, princeza, kralj, klaun, gospodin, gospođica. Nakon toga se dodaje tekst poput sljedećih rečenica: „What a beautiful day! Oh, long time no see! What a pleasant surprise!“. Tekst se tako postupno nadograđuje prema igrokazu, a pokret se razvija usporedno s tekstom.

Down memory lane vrlo je uspješna dramska tehnika. Učenici iz kutije izvlače predmete (sliku, malu lutkicu, prsten, torbicu, novčanik i sl.) te moraju ispričati priču o tom predmetu i navesti zašto im je to vrijedna uspomena. 
Omiljena dramska tehnika za sve dobne skupine je i tzv. benches ili silent movies. Sudionici se podijele u skupine i grupno razrade priču koja se odvija na klupi u parku. Zatim priču pred razredom odglume, ali kao u nijemom filmu. Ta je dramska tehnika izvanredan način razvijanja izražajnog pokreta i mimike lica jer gledatelj mora shvatiti o čemu je riječ bez tekstualne podloge. U toj prvoj fazi, dakle, glumi se bez teksta. Nakon toga ostali učenici raspravljaju o tome o čemu se zapravo radi u predstavljenoj sceni. Potom slijedi ponavljanje cijele scene, ali s dodanim tekstom.

Nadalje, dinner party je izvrsna tehnika za improvizirane dijaloge na naprednijim stupnjevima učenja stranog jezika. Sastoji se od toga da učenici sjede za stolom i jedan započinje dijalog rečenicom: „Have you seen Gladys lately?“. Drugi učenik nastavlja sa spontanom reakcijom, na primjer: "No, I haven't. Tom told me she got divorced and lives in Mallorca now". Na taj se način priča nadograđuje, a učenici se postupno uživljavaju u svoje likove i preuzimaju različite identitete s njima svojstvenim načinima govora i pokretima.

\section{PROCES STVARANJA PREDSTAVE}

\subsection{Odabir dramskoga teksta}

Prvi korak u postavljanju predstave na stranom jeziku u razredu koji je već senzibiliziran za dramske tehnike svakako je izbor dramskog teksta. Nastavnik mora uzeti u obzir nekoliko važnih elemenata: dužinu predstave, broj likova i jezičnu zahtjevnost te koreografski potencijal predstave.

Dobro je započeti s kraćim tekstovima ili skečevima za školske priredbe. Magija pozornice, izloženost publici, svjetla reflektora poticajno utječu na sudionike predstave i kad se radi o kraćoj dramatiziranoj priči. Stoga će nastavnik nepogrešivo osjetiti kada može napraviti korak dalje i izabrati duži tekst.

Drugi element $\mathrm{u}$ izboru teksta je broj likova. Iznimno je važno da svaki učenik ima svoju ulogu. U praksi to često znači da treba intervenirati $u$ osnovni tekst i osmisliti i dopisati nove likove. Korisna je tehnika predstave u predstavi koja omogućuje umetanje novog komada u već postojeći, čime se dobiva veći broj uloga i svježina osnovnog narativnog tijeka. Tu tehniku primijenili smo u komadu The Show Must Go On (Via, 1976) koji je izvela dramska grupa The English Theatre for Children Suvag u Kazalištu Komedija 2004. U osnovni tekst koji govori o odnosima glumaca neposredno prije premijere umetnuli smo najpoznatije dijelove Shakespearove tragedije Romeo i Julija (Shakespeare, 1993) - scenu balkona, scenu susreta glavnih likova na plesu i scenu mačevanja. Arhaični jezik i atmosfera davne prošlosti obogatili su predstavu, a činjenica da glume u djelu koje je napisao Shakespeare silno je podigla samopouzdanje učenika-glumaca i potakla 
interes za djela tog dramatičara. Također, ako se radi o ulozi s mnogo teksta, ponekad je moguće tu istu ulogu raspodijeliti na dva učenika-glumca. $\mathrm{Na}$ primjer, u Shakespearovu djelu A Midsummer Night's Dream (Shakespeare, 1992) koji je izvela dramska grupa The English Theatre for Children Suvag u Kazalištu Komedija 2002. ulogu Pucka igrale su dvije učenice-glumice koje su istovremeno bile na pozornici što je pridonijelo dinamici predstave.

Treći važan element u izboru teksta je stupanj njegove jednostavnosti, odnosno kompleksnosti. Naime, poželjno je da jezik dramske predstave bude u skladu s jezičnim kompetencijama sudionika. Trebalo bi izbjegavati vokabularom zahtjevne tekstove.

Sljedeći element važan pri izboru teksta je koreografski potencijal koji krije. Mogu li se uklopiti koreografirane točke plesa, ima li podloge za dinamični scenski pokret pitanja su koja će iznimno utjecati na atraktivnost predstave i s aspekta samih sudionika i s aspekta publike. Također, veće zajedničke koreografije važne su i zbog činjenice što u njima sudjeluju svi, dakle i učenici s manjim ulogama.

Međutim, čak i ako se svi navedeni elementi nađu zajedno, izbor nikako još nije konačan. Najvažnija pretpostavka prije konačne odluke jest ta da se komad mora podjednako svidjeti učenicima kao i njihovu nastavniku. Ako je recepcija nakon upoznavanja s tekstom i likovima mlaka, bolje je pronaći i ponuditi drugi komad. Ovdje se nastavnik ravna intuicijom. Prema našem iskustvu, mlađi učenici preferirat će dramatizirane bajke (npr. Crvenkapicu, Cvilidretu, Tri praščića) i basne, a osobito im se sviđaju ritmizirani tekstovi kao što su poznati Jazz Chant Fairy Tales (Graham, 1988). Također, životinjski likovi iznimno su popularni među učenicima. Osim navedenog, komedije ili kraći tekstovi s komičnim efektom generalno su popularniji od ostalih žanrova. Inspirativni kraći tekstovi (Case i Wilson, 1979) vrlo su popularni među učenicima različite dobi. Stariji učenici s naprednijim stupnjem znanja jezika vole svjetski poznata dramska djela.

\subsection{Adaptacija scenarija}

Nakon izbora teksta slijedi adaptacija scenarija koju nastavnik radi prije prvih čitalačkih proba iako su promjene ili nadopune moguće i u procesu pripreme predstave. Taj zadatak može biti vrlo zahtjevan i predstavlja velik izazov. Navest ćemo nekoliko primjera s različitim tipovima adaptacija teksta.

Prvi, ujedno i najčešći tip adaptacije odnosi se na skraćivanje originalnog dramskog teksta. Na primjer, kada smo odabrali raditi predstavu Pygmalion (Shaw, 1994) koju je izvela dramska grupa Chatterbox na Sceni Vidra 2003., imali smo u vidu glumački ansambl, odnosno učenike. Predstava je imala zadano vrijeme od 45 do 60 minuta što je značilo da se komad morao skratiti i ograničiti na ključne scene. Pet je glavnih uloga, a bilo je ukupno deset 
učenika-glumaca. Tekst se morao razraditi tako da su sporedni glumci ponekad preuzimali dijaloge koji su u originalu pripadali replikama nekog drugog lika. U konačnici je djelo od 80-ak stranica skraćeno na 10-ak stranica, a da je pritom srž same drame ostala netaknuta. Sličan postupak primijenjen je u predstavi Shakespeare Highlights koju je izvela dramska grupa The English Theatre for Children Suvag u školi Centennial Secondary School 2008. gdje smo dramski tekst The Compleat Wks of Willm Shkspr Abridged (Long, Singer i Winfield, 1994) koji duhovito sintetizira mnoga različita djela slavnog dramatičara adaptirali napravivši izbor samo nekoliko djela (Romeo i Julija, Hamlet, Othello). Pritom su dvije pretpostavke bile temelj izbora. Prvo, postojeći glumački ansambl i činjenica da su u skupini od deset učenika gotovo svi imali prilike igrati glavne uloge u svom segmentu predstave - imali smo uloge Romea i Julije, Othella, Hamleta i Ophelije, Benvolia i Tybalta i slično. Drugo, birali smo najpoznatije dijaloge i monologe iz svjetske povijesti dramske književnosti koji su dodatno motivirali učenike-glumce.

Drugi tip adaptacije odnosi se na umetanje potpuno nove scene $\mathrm{u}$ okvir zadane predstave. U predstavi San ljetne noći (Suvag, Hrvatsko narodno kazalište, 2013) inspiriranoj motivima iz poznatog Shakespearova djela osmislili smo scenu koja zapravo u originalu ne postoji. Učenici su na dvoru trebali poučavati vojvodu lijepom ponašanju. Nastavnik je imao zadatak izmisliti čitavu priču uzimajući u obzir stil i jezik toga vremena i, naravno, tipično englesko ponašanje, vodeći računa o tome da sve bude pristupačno i razumljivo učenicima. Scena se sastojala od uobičajenih situacija na engleskom dvoru - razgovora o vremenu, što obući i kako se nakloniti kraljici, kada je vrijeme za čaj i kako se ponašati na konjskim trkama. U tu je scenu također implementirana i glazba toga vremena kao i ples što je $u$ konačnici dočaralo bajkovitu atmosferu originalnog djela.

$\mathrm{S}$ trećim tipom adaptacije susreli smo se kada smo radili na predstavi The Mousetrap (Christie, 1995) koju je izvela dramska grupa Chatterbox na Sceni Vidra 2009. Ovdje smo dodali i nove likove i nove scene. Taj je komad klasičan whodunnit, ali na kazališnim daskama na stranom jeziku činio se dosta statičnim. Stoga smo odlučili napraviti neke izmjene. Radnja je ostala ista, ali smo uveli nove likove i to dvije sobarice koje su nakon svakog čina davale svoje duhovite komentare na to što se na sceni odvijalo i same se igrale privatnih istražitelja koji ne prežu ni od čega kako bi pronašle zloglasnog ubojicu. Inspiracija nam je ovdje bila serija Zvonili ste milorde i sobarica Ivy, film Gosford Park i serija Downton Abbey koja je učenicima bila dobro znana. Na samoj su predstavi upravo ti umetnuti dijelovi zaslužili najveći pljesak.

Četvrti tip adaptacije je umetanje predstave u predstavu kao što smo napravili s prethodno spomenutom predstavom The Show Must Go On $\mathrm{u}$ kojoj su likovi glumci koji pripremaju predstavu $\mathrm{u}$ atmosferi velikog uzbuđenja i napetosti pred premijeru. Tekst smo ostavili cjelovitim, ali smo 
dodali i najpoznatije scene iz Shakespearova djela Romeo i Julija kao dijelove predstave koju ti isti glumci uvježbavaju i koju će neposredno poslije izvesti pred publikom. Ta adaptacija omogućila je više glavnih uloga, produžila predstavu i spojila moderni i arhaični engleski jezik, odnosno nepoznate likove iz suvremenosti s poznatim likovima iz prošlosti. Pritom je cjelokupna atmosfera dvaju segmenata predstave bila potpuno različita - osim jezika kojim likovi govore, različiti su bili i glazba, scenografija i kostimi.

Važno je napomenuti da u adaptaciji scenarija, osim nastavnika, i učenici mogu biti kreativno uključeni, što može rezultirati sjajnim i upečatljivim novim sporednim likovima.

\subsection{Opći uvod, čitalačke probe, dodjela uloga}

Nakon izbora teksta slijedi jedan opći uvod u kojem će nastavnik govoriti o autoru, povijesnom ili književnom razdoblju u kojemu je dramski tekst nastao, prvim izvedbama i recepciji. Također, nastavnik će opisati likove i radnju kako ih sam doživljava i potaknuti razgovor o tome što nam se sviđa u predstavi. Pritom će uvesti učenike u osnovni vokabular koji se koristi u kazalištu.

Međutim, najvažniji dio tog općeg uvoda je detaljan razgovor o likovima. Potrebno je što preciznije opisati likove, njihovu dob, zanimanje, osobnost, fizički izgled. Također, važno je likove smjestiti u prostor i vrijeme te objasniti njihove motive, odnosno zašto govore i rade to što govore i rade. Detaljni kontekst pomoći će učenicima da intenzivno dožive lik i na tome grade svoju interpretaciju.

Zatim slijede čitalačke probe $u$ kojima se svladava tekst $i$ objašnjava nepoznati vokabular. Važno je naglasiti da se još ne dodjeljuju uloge te da će tek nakon nekoliko sati proba uloge biti dodijeljene. U početku se tekst svladava sjedeći. Vrlo brzo, međutim, prije nego što se tekst nauči napamet, učenici počinju glumiti scene stojeći i koristeći se govorom tijela pa makar i s tekstom u ruci. Također, potrebno je varirati uloge među učenicima da svi dobiju priliku i da u konačnici prava uloga „pronađe“ svog učenika.

U početku je poželjno usredotočiti se na važnije dijelove teksta te ih ponavljati varirajući kontekst. Isti tekst može se izgovarati s osjećajem ljutnje, tuge, zaljubljenosti. Opća atmosfera koja definira scenu također se može mijenjati - od prijateljske i vesele do napete i teške. Ovaj dio rada učenici jako vole jer izraženija ekspresija često izaziva komične efekte, a smijeh u razredu opušta i nadahnjuje.

Također, vrlo je učinkovito mijenjati muško-ženske uloge. Ako dječak glumi djevojčicu (ili obrnuto) osim izrazitog komičnog efekta dobit će se i otkrivanje unutrašnjosti lika. Naime, čim se očigledna fizička različitost između lika i njegova interpretatora prihvati, pozornost ide u smjeru samog karaktera lika, njegovih unutarnjih osobina i motiva te teksta koji ga otkriva. 
Na primjer, kada smo pripremali Romea i Juliju, ulogu Julije igrao je dječak što je djelu dalo sasvim novu dimenziju.

\subsection{Scenski pokret i glazba}

Razdoblje između prvog susreta s dramskim tekstom, odnosno prvih čitalačkih proba i prvih proba koje uključuju scenski pokret vrlo je kratko. Razlog tomu je činjenica da pokret izravno utječe na prirodnost govora i artikulaciju te izravno pridonosi opuštenosti. Međutim, za razliku od teksta koji je zadan - bez obzira na promjene i moguću „otvorenost“ - pokret nije unaprijed određen. Učenici-glumci kreću u nepoznato, bez uputa kako osmisliti scenski pokret. U ovoj je početnoj fazi postavljanja predstave važno poticati kreativnost učenika te ga pustiti da sam osmisli pokrete. Nastavnik se potom i sam pridružuje izgradnji scenskog pokreta dopuštajući varijacije i promjene. U ovom segmentu pripreme predstave nastavnik i učenici jednako su neiskusni stoga je važna fleksibilnost i isprobavanje. Uvažavajući prijedloge učenika nastavnik iskazuje poštovanje, često i divljenje, a to svakako djeluje poticajno na sudionike. Stvara se osjećaj zajedništva te učenici doživljavaju predstavu kao svoj projekt.

Poteškoće na koje pritom nastavnik nailazi odnose se na manjak adekvatnog prostora što u konačnici znači da se probe odvijaju u prostorima postojećih učionica s klupama pomaknutima u stranu. Veličina učionica nikad nije usporediva s veličinom scene te ta zbijenost $\mathrm{i}$ „zguranost" može utjecati na teže snalaženje na velikoj površini prave pozornice. Također, nastavniku nije lako kontrolirati sam proces probe. To je, naime, nova situacija u kojoj svi govore i kreću se, nema tišine i teže je postići usredotočenost.

$\mathrm{Uz}$ to, učenici vrlo brzo nauče tekst napamet te osjećaju sigurnost $\mathrm{u}$ govoru i pokretu što često rezultira efektom „prenaučenosti“, naime govore prebrzo i artikuliraju nejasno. Usporavanje govora i „stišavanje“ ekspresije možda je najveći izazov nastavniku koji traje do samoga kraja, do premijere.

Novi zamah pripremi predstave uvođenje je stručnjaka za scenski pokret, odnosno koreografa koji će raditi na pokretu vezanom za riječ, ali i osmisliti samostalne koreografije unutar predstave. Pritom je ključna uloga nastavnika stranog jezika koji jasno definira svoju viziju predstave te pomaže u razumijevanju teksta. Na primjer, u predstavi Rumpelstiltskin kojoj je temelj poznata bajka (The English Theatre for Children Suvag, Kazalište Komedija, 2000) koreograf je uveo plesnu točku koja je ilustrirala vatru, u prethodno spomenutim predstavama The Show Must Go On uveo je veliku točku dvorskog plesa, u predstavi A Midsummer Night's Dream šumski ples vila, u Pygmalionu poznatu plesnu točku The Rain in Spain Stays Mainly in the Plain (My Fair Lady, 1956). Zajedničke su koreografije element predstave koji vole svi sudionici, a znatno pridonose vizualnom bogatstvu predstave. 
Koreograf u suradnji s nastavnikom bira glazbu za predstavu, ali svi sudionici mogu iznositi svoje prijedloge, a dobro je to izravno od njih i tražiti jer mladi svojim osebujnim ukusom i poznavanjem suvremenih glazbenih trendova mogu unijeti dozu iznenađenja i svojevrsne prpošnosti u glazbeni okvir predstave. Na primjer, u predstavi The Mousetrap za glazbenu podlogu izabrali smo glazbu iz pedesetih godina 20. stoljeća.

\subsection{Scenografija i kostimi}

Izradi scenografije pristupa se kada je priprema predstave već dobila zamah, kada je scenski pokret i vizualni identitet predstave osmišljen. Osnovno je pravilo jednostavnost. Naime, u ovom segmentu nastavnik sam osmišljava osnove scenografije, a u izradi mu pomažu kolege nastavnici likovnog odgoja, volonteri, učenici ili čak njihovi roditelji. Uz to, scenografija bi trebala biti lako prenosiva zbog gostovanja u različitim kazalištima ili školama. U nabavi rekvizita također sudjeluju svi. Korištenje rekvizita, međutim, traži dodatni angažman učenika i nastavnika jer nemaju na raspolaganju tehničko osoblje.

Navodimo primjere rada na tom segmentu pripreme predstave. Kada smo postavljali prethodno spomenutu predstavu Pygmalion odlučili smo da čitava predstava ima crno-bijeli vizualni identitet. Kostimi su bili u nijansama crne, sive i bijele, a sama scenografija bila je napravljena od dviju golemih kartonskih kutija koje nam je oslikala akademska slikarica-volonterka i to sve u crnim tonovima. Svaka strana tih kutija predstavljala je drukčiju scenu Covent Garden, engleski park, fonetski laboratorij, salon itd. Nakon svakog čina sami bi glumci okretali te kutije i tako mijenjali mjesto događanja.

S predstavom The Mousetrap imali smo prekooceanska gostovanja pa smo morali voditi računa o tome da nemamo preglomaznu i tešku scenografiju zbog transporta. Scenografija se mijenjala tako da smo se koristili onim što nam je bilo na raspolaganju u kazalištu u kojem smo nastupali (stolovi, fotelje, škrinje, klavir, ormarići), a sa sobom smo uvijek imali slikarski stalak i sliku Van Goghovih Suncokreta, kao i natpis Monkwell Manor.

Predstava The Importance of Being Earnest (Wilde, 2008) koju je izvela dramska grupa Chatterbox u Satiričkom kazalištu Kerempuh 2010. imala je drukčije rješenje. Fotografirali smo tipični engleski dnevni boravak i dali ga uvećati na veliko platno. Na drugo platno dali smo otisnuti uvećanu Monetovu sliku parka s lopočima i to je na efektan način služilo kao pozadina.

Za vrijeme proba u kazalištu s majstorima rasvjete prvo smo učili, a zatim osmišljavali vrste svjetla primjerene određenoj sceni, te odlučivali kada upotrijebiti reflektorsku rasvjetu, kada prigušeno ili dnevno, hladno ili toplo svjetlo. Iako je nastavnik razradio detaljne upute o upotrebi svjetla kroz tekst, ovdje nam je ponovno bila potrebna pomoć volontera koji bi 
za vrijeme održavanja predstave signalizirao majstoru rasvjete, koji nije poznavao scenarij predstave, promjenu rasvjete.

Kostimi, za razliku od scenografije, zahtijevaju angažman profesionalcakostimografa. Čak i ako kostimograf poslu pristupa kao volonter, nabavka materijala za šivanje traži dodatna financijska sredstva. Stoga je podrška matične institucije vrlo važna. U našim predstavama volontirali su i modni dizajneri, a neke smo kostime posuđivali iz kazališnih institucija.

Međutim, dizajniranje i potom probe kostima, prema našem iskustvu, unose pozitivnu dinamiku među učenicima te ih dodatno motiviraju.

\subsection{Budžet i promotivni materijali}

Dramska radionica i priprema predstave traže dodatna financijska sredstva za troškove izrade kostima i angažmana kostimografa, koreografa i snimatelja, izrade promotivnih materijala (programa predstave, snimanja predstave, portfolija dramske grupe), ponekad i troškove najma kazališta te putne troškove za sudionike pri gostovanjima u inozemstvu. Nastavnik je $\mathrm{s}$ roditeljima angažiran $u$ traženju sponzora što je težak i dugotrajan proces koji iziskuje punu posvećenost, administraciju i vrijeme.

Promotivni materijali uključuju izradu programa predstave, plakata i portfolija dramske grupe. I ovdje je angažiran nastavnik, ali i volonterstručnjak za grafički dizajn. Video snimke predstave najčešće se izrađuju tijekom same predstave u kazalištu, ali i prije same premijere. Naime, za sudjelovanje na međunarodnim kazališnim festivalima potrebnoje prethodno poslati snimku predstave zbog recenzije i izbora. Kako se snimanje obavlja u prostorijama razreda gdje je prostor skučen, a dobra kvaliteta zvuka teško ostvariva, to je dodatni izazov.

\subsection{Gostovanja i suradnja na medunarodnoj razini}

Postoje dvije vrste međunarodnih gostovanja koje može ostvariti školska dramska grupa. Prvo su međunarodni kazališni festivali za djecu ili mlade kao što su poznati festival u Toulouseu (Francuska), Mont Laurieru (Kanada) te Milevskom (Češka Republika). Potrebno je pratiti natječaje i prijaviti predstavu. Ako je predstava uvrštena u program festivala, onda organizator najčešće preuzima brigu o smještaju, što znatno olakšava organizaciju puta.

Druga vrsta međunarodnih gostovanja organizira se na razini institucija, najčešće dviju ili više škola. Dobar su izbor škole koje imaju u svom programu dramske radionice jer osim zajedničkog interesa najčešće imaju i adekvatnu pozornicu unutar škole. Uz to, djeca su smještena u obiteljima djece koja pohađaju inozemnu školu, pa osim stjecanja novih prijatelja gostovanje pridonosi upoznavanju strane kulture na najbolji mogući način. Također, takav tip međunarodnih gostovanja uvijek je i promocija institucije 
i Republike Hrvatske te su vrlo zapaženi u stranim lokalnim medijima što je dodatni poticaj sudionicima.

Međutim, u oba navedena slučaja suočavamo se s doneklenepredvidivom situacijom. Naime, činjenica da je predstava na engleskom jeziku olakšava praćenje publici na inozemnim gostovanjima, ali predstava se doživljava kao kazališni komad, dakle kroz percepciju temeljenu na umjetničkom doživljaju, dok se edukativni element, odnosno činjenica da je predstava izrasla iz nastave engleskoga kao stranog jezika gubi iz vida. Dakle, za razliku od ostalih sudionika međunarodnog kazališnog festivala ili dramske grupe u školi koja je domaćin gdje učenici-glumci glume na materinskom jeziku, veliko postignuće naših učenika-glumaca koji glume na stranom jeziku ostaje nezapaženo. Stoga je ukupan pristup pripremi predstave na engleskom jeziku suočen s novim izazovima.

Ovisno o interesu strane škole, uz predstavu kao središnji događaj može se osmisliti i prezentacija vlastite zemlje u koju su uključeni svi učenici. U suradnji s turističkim zajednicama moguće je nabaviti postere s ljepotama Hrvatske kao i suvenire-poklone. Vrlo često gostovanje dramske grupe s predstavom za inozemnu školu znači i svojevrsni hrvatski tjedan, a za naše učenike priliku da predstave svoju zemlju. Djecu su kao uspješne ambasadore svoje zemlje prepoznala i mnoga hrvatska veleposlanstva koja su za vrijeme naših gostovanja organizirala susrete $s$ djecom i na druge načine davala podršku projektu.

\section{ZAKLJUČAK}

Dramska radionica na engleskom jeziku ima potencijal prerasti $u$ veliki projekt koji uključuje edukativne, umjetničke i kulturološke sadržaje. Međunarodna gostovanja dodatni su motiv. Projekt se najvećim dijelom oslanja na inicijativu i angažman nastavnika, ali se može realizirati samo uz podršku matične institucije, roditelja i šire društvene zajednice. Djeca koja su uključena u projekt, engleski jezik ne doživljavaju kao školski predmet, nego kao živo sredstvo komunikacije koje im donosi osjećaj velikog postignuća, ispunjenosti i radosti baš kao i njihovim nastavnicima.

\section{LITERATURA}

Belliveau, G. i Kim, W. (2013) Drama in L2 Learning: a Research Synthesis. Scenario 7 (2), 7-27.

Boudreault, C. (2010) The Benefits of Using Drama in ESL/EFL Classroom. The Internet TESOL Journal, 16 (1). http://iteslj.org/Articles/Boudreault-Drama.html (4. 8. 2019.)

Case, D. i Wilson, K. (1979) Off-stage!: Sketches from the English Teaching Theatre. London: Heinemann.

Christie, A. (1995) The Mousetrap and Selected Plays. London: HarperCollins Publishers Ltd.

Dougill, J. (1987) Drama Activities for Language Learning. London i Basingstoke: Macmillan Publishers.

Dundar, S. (2013) Nine Drama Activities for Foreign Language Classrooms: Benefits and Challenges. Procedia - Social and Behavioral Sciences, 70, 1424-1431. 
Gavrilović Smolić, T. (2019) Pokret i prostor u poučavanju engleskoga jezika. U Vrhovac, Y. (ur.) Izazovi učenja stranoga jezika u osnovnoj školi. Zagreb: Ljevak, 432-439.

Graham, C. (1988) Jazz Chant Fairy Tales. Oxford: Oxford University Press.

Lesar Dolenc, L. (2019) Dramski pristup u nastavi njemačkoga jezika. U Vrhovac, Y. (ur.) Izazovi učenja stranoga jezika u osnovnoj školi. Zagreb: Ljevak, 389-394.

Long, A. Singer, D. i Winfield, J. (1994) The Compleat Wks of Willm Shkspr Abridged. New York i London: Applause Books.

Maley, A. i Duff, A. (2013) Drama Techniques: a Resource Book of Communication Activities for Language Teachers (3. izdanje). Cambridge: Cambridge University Press.

Nikpalj, V. (2015) Elements of Drama in Teaching English to Young Learners. U Mihaljević Djigunović, J. (ur.) Children and English as a Foreign Language. Zagreb: FF press, 83-95.

Ntelioglou, B. Y. (2011) Drama and English Language Learners. U Schonmann, S. (ur.) Key Concepts in Theatre/Drama Education. Rotterdam: Sense Publishers, 183-188.

Phillips, S. (1999) Drama with Children. Oxford: Oxford University Press.

Ryan-Scheutz, C. i Colangelo, L. M. (2004) Full-Scale Theater Production and Foreign Language Learning. Foreign Language Annals 37 (3), 374-385.

Shakespeare, W. (1992) A Midsummer Night's Dream. New York: Dover Publications Inc.

Shakespeare, W. (1993) Romeo and Juliet. New York: Dover Publications Inc.

Shaw, G. B. (1994) Pygmalion. New York: Dover Publications Inc.

Via, R. A. (1976) English in Three Acts. Honolulu: East-West Center University Press of Hawaii.

Vican, D. i Milanović Litre, I. (ur.) (2006) Nastavni plan i program za osnovnu školu. Zagreb: Ministarstvo znanosti, obrazovanja i športa.

Wilde, O. (2008) The Importance of Being Earnest and Other Plays. Oxford: Oxford University Press. 


\section{FROM DRAMATIZATION TO PERFORMANCE IN ENGLISH LANGUAGE TEACHING}

The aim of this paper is to present the process of creating a play in English with elementary and / or high school students of EFL. The starting point of this process is the use of drama techniques in the English language teaching. The paper mentions the most prominent drama techniques and the advantages of their use and describes the process of preparing a play with numerous examples. The process begins with the selection of the play and adaptation of the script, followed by reading rehearsals and role assignments, work on stage movement, choice of music, set and costumes. Descriptions of the required budget for the play, the creation of promotional material and international cooperation have also been given. A performance in English is a significant project that follows the founding of a drama workshop. The final result includes educational, artistic and cultural content, encourages motivation and generates new approaches to learning English.

Keywords: drama techniques, EFL teaching, performing in English, script adaptation. 